\title{
Efficacy of Different Fungicides Against Rhizome Rot Disease of Ginger Under Farmer Field Condition in Salyan, Nepal
}

\author{
Resham B, Amrita P*, Anish P, Bikash G and \\ Babu BK \\ Agriculture and Forestry University, Bharatpur, Nepal \\ *Corresponding author: Paudel Amrita, Agriculture \\ and Forestry University, Bharatpur, Nepal
}

Received: July 27, 2021; Accepted: August 28, 2021; Published: September 04, 2021

\begin{abstract}
A study was conducted from March to August 2020 to evaluate the effectiveness of different fungicides for the management of rhizome rot disease in ginger. The field experiment was conducted under Randomized Complete Block Design with four replication and five treatments; Carbendazim 50\% WP @ 1gm/litre + Mancozeb 75\% WP @ 2.5gm/litre, Metalaxyl 8\% WP + Mancozeb 64\% WP @ 2gm/litre, Carbendazim 50\% WP @ 1gm/litre, Trichoderma viride $@ 5 \mathrm{gm} /$ litre and control. The height of pseudo stems, leaf number, germination percentage, tiller number, disease incidence, disease severity and percentage of disease control was recorded during field experiment. There was no significant effect of pre sowing rhizome treatment in height of pseudostems, leaf number and germination percentage. The highest tiller number (3.40) was found with Carbendazim 50\% WP @1gm/litre + Mancozeb 75\% @ 2.5gm/ litre treatment and lowest tillers number (2.95) was found with control. The highest disease incidence (34.37) and severity (30.03) was found in control plot whereas the lowest disease incidence (2.58) and disease severity (2.46) was found with Carbendazim 50\% @ 1gm/litre treatment + Mancozeb 75\% @ $2.5 \mathrm{gm} /$ itre. Similarly, the highest percentage disease control (85.61) was found with Carbendazim 50\% @ 1gm/litre + Mancozeb 75\% @ 2.5gm/litre treated rhizome and the lowest (54.14) was found with Trichoderma viride @ 5gm/litre treatment. Therefore, seed treatment with Carbendazim 50\%WP @ 1 gm/litre + Mancozeb 75\% WP @ $2.5 \mathrm{gm} /$ litre is found effective among other fungicides in Bagchaur-3, Salyan and is recommended for enhancing tiller and reducing rhizome rot disease incidence and severity in ginger.
\end{abstract}

Keywords: Rhizome rot; Ginger; Fungicides; Disease incidence

\section{Introduction}

\section{Background information}

Ginger is among Nepal's most significant spice crops, produced in the mid-hills as high-value commodities with strong export potential [1]. Approximately $40 \%$ of ginger produced is utilized as planting material, $40 \%$ is shipped to other nations, and $20 \%$ is utilized in the country for domestic consumption and medical purposes [2].

Salyan exhibits numerous agricultural potentialities as it is one of the potential areas of ginger farming in Nepal and ranks second in ginger production in the country. Average land under ginger cultivation in Dadagaun VDC (one of the most ginger cultivation areas of Salyan) was found 2.17 ropani [3]. Malneta (one of the most ginger cultivation areas of Salyan) in Sarada municipality has historically been recognized as the national production center for quality ginger. Malneta sutho has a lemony white color and a strong flavor, making it a popular choice with traders. There are two traditional varieties of ginger found in Salyan namely Nashe (the one with more fibre inside) and Boshe (the one with less fibre inside and more productive [1] (Table 1).

Ginger contains several biological compounds that have been used for a variety of therapeutic purposes, including pain relief, lowering cholesterol levels in the blood, aiding digestion and absorption, and relieving constipation and diarrhea by increasing the activity of muscle fibers in the intestinal tract [5]. Fresh ginger, ginger powder from dry ginger and oil are used for medicinal purposes. It is used as antimicrobial, antioxidant, anti-inflammatory, anticancer, neuroprotective, cardiovascular protective, respiratory protective, antiobesity, antidiabetic, antinausea, and antiemetic agents [6].

Ginger is affected by many diseases that include rhizome rot, leaf spot (Phyllosticta), rot in storage, wilt by a bacterium, mosaic, and chlorotic fleck [7]. Among these, rhizome rot disease of ginger is the most devastating disease with an average estimated yield loss of $20 \%$ [8]. Soft rot is known to destroy 75\% [9]. Rhizome rot is caused by fungus (Pythium spp. and Fusarium oxyporium f. sp. zingiberi) and bacteria (Pseudomonas (Ralstonia) solaniserum) [10], which can survive in the soil for long periods resulting in loss of total production if infection initiates at the early stage of plant growth. Soft rot disease is caused by Pythium spp. Among them, Pythium aphanidermatum is the most prevalent and widely distributed species [11]. The disease caused by Pythium myriotylum spread at the rate of up to $4.5 \mathrm{~m} /$ day [12]. The causative agent of dry rot is Fusarium spp [13]. Rhizome rot symptoms can appear at any phase of a crop's development, although they're more prevalent in the summer and autumn when the crop is 
Table 1: Area, production and productivity of ginger in Salyan.

\begin{tabular}{|c|c|c|c|}
\hline Years & Area in hectares & $\begin{array}{c}\text { Production in metric } \\
\text { tons }\end{array}$ & $\begin{array}{c}\text { Productivity in } \\
\text { mt/ha }\end{array}$ \\
\hline $2013 / 14$ & 24226 & 276150 & 11.4 \\
\hline $2014 / 15$ & 23826 & 242547 & 10.18 \\
\hline $2015 / 16$ & 21869 & 271863 & 12.43 \\
\hline $2016 / 17$ & 22649 & 279504 & 12.34 \\
\hline $2017 / 18$ & 23000 & 284000 & 12.35 \\
\hline $2018 / 19$ & 22132 & 297512 & 13.44 \\
\hline
\end{tabular}

expanding fast [12].

Selection of healthy rhizome seed, disease resistance varieties (kapurkot aduwa-1and and kapurkot aduwa-2), crop rotation, soil treatment (soil solarization) and rhizome seed treatment with fungicides is the main production technologies recommended to control the disease. Seed treatment with $0.2 \%$ Ridomil MZ + 0.1\% Carbendazim 50\% WP was recommended for control of rhizome rot [14]. Pythium aphanidermatum rhizome rot was efficiently controlled by seed dip in 0.1 percent Metalaxyl MZ, with the minimum disease incidence (4.23 percent) and the maximum disease elimination (88.855 percent) [15]. Rhizome of ginger can be managed by the application of Ridomil MZ 72\% WP (Metalaxyl $8 \%+$ Mancozeb 64\%) with $81.6 \%$ plant survival [16]. The combined use of $4 \mathrm{ml}$ Chloropyrifos +2.5 gm Dithane M- $45+1 \mathrm{G}$ Bavistin per litre water in two stages (seed rhizome treatment before planting and soil drenching one month after ginger germination) was found most effective for rhizome rot disease control as well as rhizome rot fly [17]. Seed treatment with Trichoderma viride @ 4g/10 litre water per $\mathrm{kg}$ of seed resulted in a low plant death $(4.2 \%)$ when compared to disease control (84.9 percent) [18]. In the rhizome medicated with Trichoderma viride, disease infection was observed at a minimal of $3.80 \%[19,20]$ found that the Ridomil Gold MZ 68 (Mancozeb 64\% $\mathrm{W} / \mathrm{W}+$ Metalaxyl-M 4\% W/W) treated plot had the maximum yield (18.08t/ha). Similarly, 0.1\% Bavistin (Carbendazim 50\% WP) +0.25 Indofil M-45 (Mancozeb 75\% WP) was found effective from disease management point of view with yield 19.3-22.5 mt/ha [21]. The usage of $4 \mathrm{ml}$ Chloropyrifos $+2.5 \mathrm{gM}$ Dithane M- $45+1 \mathrm{G}$ Bavistin per litre water in two phases (seed rhizome treatment prior to planting and soil soaking one month after ginger germination) results in the highest production $(20.89 \mathrm{mt} / \mathrm{ha})$ and the lowest $(0.32 \mathrm{mt} / \mathrm{ha})$ rhizome fly affected rhizome [17]. Mulching may alter the physio-chemical conditions of the soil, leading to enhanced phosphorus and potassium availability [22].

\section{Statement of problem}

Farmers in the Salyan district have been facing numerous problems regarding ginger cultivation. Among all the diseases, rhizome rot disease appears to be the most recent and potentially devastating threat in the Salyan area. Pythium and Fusarium spp are very common and widespread pathogens in ginger growing areas of the Salyan district. Heavy infestation of rhizome rot disease in the study area has caused a great loss to the farmer in past years. About 70 percent of ginger is reported to be lost in the field and during storage due to rhizome rot disease of ginger [23]. About 50\% ginger production loss by rhizome rot in Nepal [24]. Every year, farmers grow ginger on 2035 hectares of land with the hope of generating good profit [25]. Rhizome rot disease is more common during rainy seasons [8]. Therefore, rhizome rot is the major problem of the ginger farmer of the Salyan district.

\section{Rational of study}

Salyan is the potential ginger producing district in Karnali province. In Salyan, no systematic research work has been done on the control of rhizome rot disease in ginger. It is very important to identify the factors affecting disease incidence and disease severity and to develop control measures for rhizome rot. Among various cultural, physical, chemical, biological methods, etc. rhizome rot of ginger can be decreased with the application of appropriate fungicides efficiently [26]. Several chemical pesticides have been studied and utilized in the field for rhizome rot disease management, including Carbendazim 50 percent WP+ Mancozeb 75 percent WP, Metalaxyl 8 percent WP + Mancozeb 64 percent WP, and Saf [27]. Similarly, various national and international articles and journals have clearly stated the fungicidal use in the rhizome rot disease management that may include Metalaxyl 8\% WP + Mancozeb 64\% WP, Carbendazim $50 \%$ WP and Mancozeb 75\% WP [28] as well as biological agents like Trichoderma viride [29]. This research targets to use of various biological and chemical fungicides for the best management of those diseases to satisfy the farmers the production. This research will be fruitful for ginger producing farmers.

\section{Objectives of the research}

General objective: To determine the efficacy of various fungicides in preventing ginger rhizome rot disease.

\section{Specific objectives:}

- To identify the incidence and severity of rhizome rot disease of ginger in field condition of Salyan.

- To evaluate the performance of various fungicides against rhizome rot.

- To compare the effect of fungicide treatments in growth parameters.

\section{Methodology}

Action research was conducted to identify effective fungicide having best control over rhizome rot of ginger at PMAMP ginger/ turmeric zone area of Salyan during 2020. The detail of experiment methods is described in the following sub-headings.

\section{Research site}

The experiment was conducted at Bagchaur-3, Salyan, which lies in the mid-hill region of Nepal. It lies at about latitude $28^{\circ} 31^{\prime}$ to $28^{\circ} 53^{\prime} \mathrm{N}$ and longitude $82^{\circ} 0$ to $82^{\circ} 46^{\prime} \mathrm{E}$ at an altitude ranging from above 1530 meters above the sea level [30]. The average rainfall over the year in the district is $1287 \mathrm{~mm}$ and $80 \%$ of the rainfall occurs from Jestha to Bhadra. The average maximum and minimum temperature of the district is 23 and 10.4 (Figure 1).

\section{Research design}

The method used in this research was single factor Randomized Complete Block Design (RCBD). The experiment was conducted with 4 replications having 5 treatments (Table 2 ).

The individual plot was $3.6 \mathrm{~m}^{2}\left(3 \mathrm{~m}^{\star} 1.2 \mathrm{~m}\right)$ with row to row spacing 


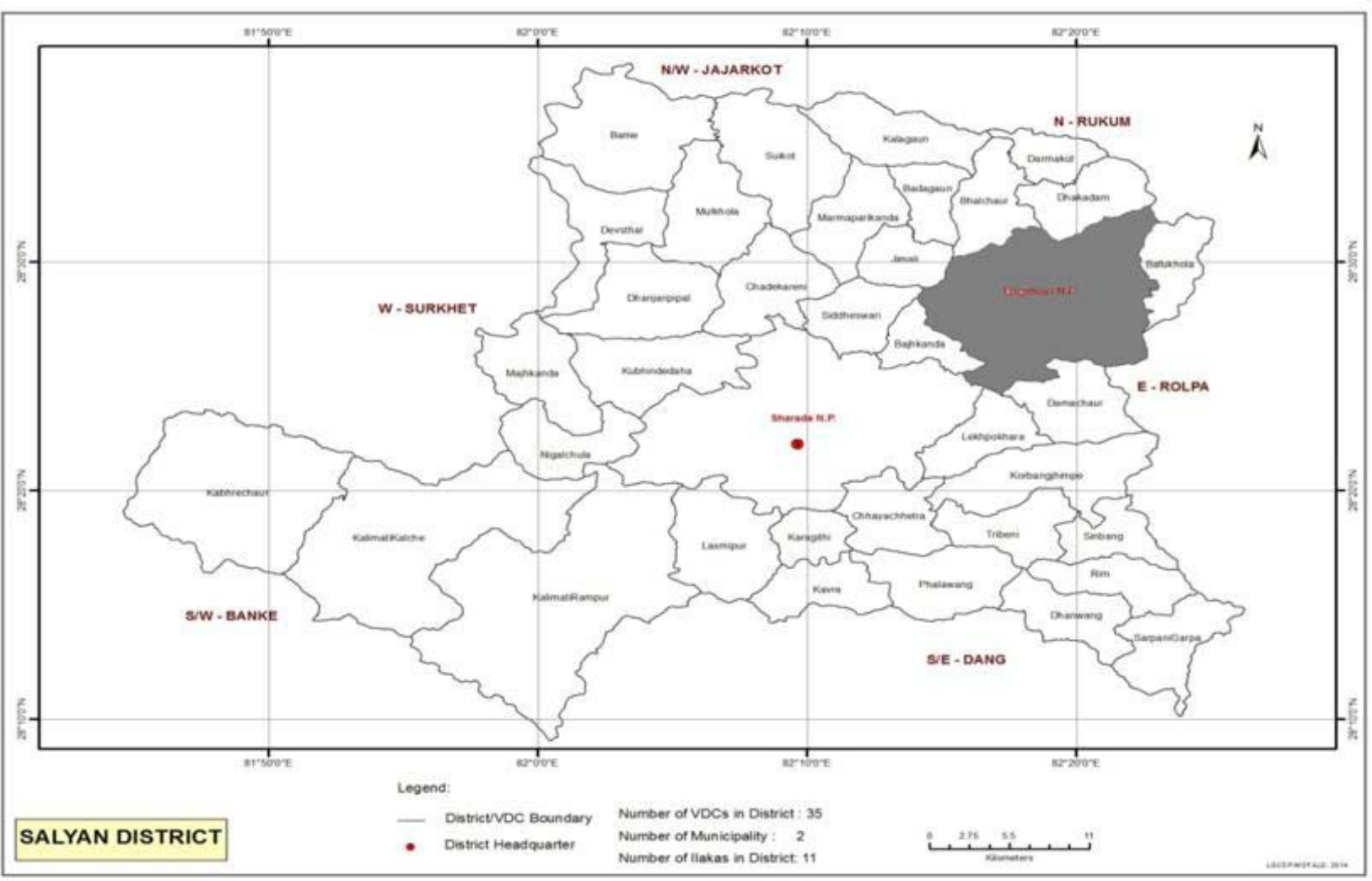

Figure1: Map of Salyan district.

Table 2: Various treatments with detailed description.

\begin{tabular}{|c|c|c|c|c|}
\hline Treatment & Trade Name & Common Name & Dose & Type \\
\hline $\mathrm{T} 1$ & $\begin{array}{l}\text { Bavistin+ Indofil } \\
M-45\end{array}$ & $\begin{array}{c}\text { Carbendazim } 50 \% \text { WP+ Mancozeb } \\
75 \% \text { WP }\end{array}$ & $\begin{array}{c}\text { 1gm/litre (Carbendazim)and } 2.5 \mathrm{gm} / \text { litre } \\
\text { (Mancozeb) }\end{array}$ & $\begin{array}{l}\text { systemic (Carbendazim) and contact } \\
\text { (Mancozeb) }\end{array}$ \\
\hline $\mathrm{T} 2$ & $\begin{array}{l}\text { Ridomil MZ } 72 \% \\
\text { WP }\end{array}$ & $\begin{array}{c}\text { Metalaxyl } 8 \% \text { WP+ Mancozeb } 64 \% \\
\text { WP }\end{array}$ & 2gm/litre & $\begin{array}{l}\text { systemic (Metalaxyl) and contact } \\
\text { (Mancozeb) }\end{array}$ \\
\hline T3 & Bavistin & Carbendazim 50\% WP & 1gm/litre & Systemic \\
\hline $\mathrm{T} 4$ & Sanjeevani & Trichoderma viride & $5 \mathrm{gm} /$ litre & Bio-fungicide \\
\hline T5 & Control & - & - & - \\
\hline
\end{tabular}

\section{$3 \mathrm{~m}$}

\begin{tabular}{|c|c|c|}
\hline $\mathrm{T} 1$ & \multirow[t]{2}{*}{$1.2 \mathrm{~m}$} & T1 \\
\hline T4 & & T3 \\
\hline $\mathrm{T} 2$ & \multirow{3}{*}{$50 \mathrm{~cm}$} & T5 \\
\hline T3 & & $\mathrm{T} 2$ \\
\hline T5 & & T4 \\
\hline
\end{tabular}

\begin{tabular}{|l|}
\hline $\mathrm{T} 5$ \\
\hline $\mathrm{T} 4$ \\
\hline $\mathrm{T} 3$ \\
\hline $\mathrm{T} 1$ \\
\hline $\mathrm{T} 2$ \\
\hline
\end{tabular}

Replication 3

\begin{tabular}{|l|}
\hline T3 \\
\hline T2 \\
\hline T5 \\
\hline T4 \\
\hline T1 \\
\hline
\end{tabular}

Replication 4

Figure 2: Layout of the research in single factor RCBD at Salyan, Nepal.

and plant to plant spacing of $30 \mathrm{~cm}$ each. The experiment had a total area of $72 \mathrm{~m}^{2}$ and a gross area of $130.5 \mathrm{~m}^{2}$. Spacing between both the replication and treatment was $50 \mathrm{~cm}$ with a field margin of $50 \mathrm{~cm}$ on all sides. All the cultivation practices for ginger were conducted as per recommendation. Presowing treatment of the rhizomes was done with different fungicides at the recommended dose according to National Ginger Research Program Kapurkot, Salyan (Figure 2).

\section{Soil testing}

The soil sample from the research plot was taken and the $\mathrm{pH}$ 


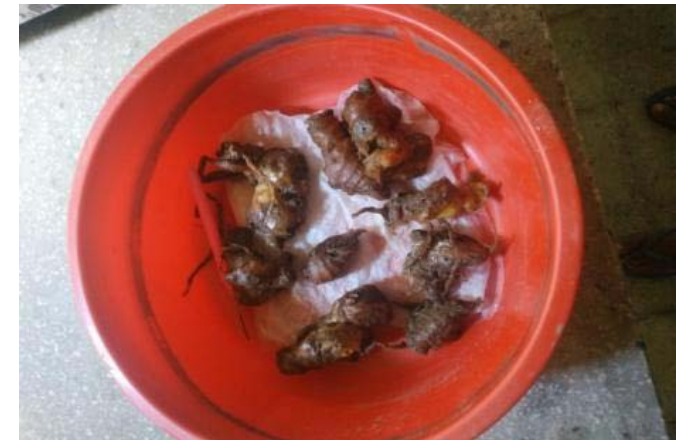

Figure 3: Disease infected rhizome of the ginger.

content of the soil was found to be 6.3 by using a ph meter and suitable for ginger farming. The nitrogen, phosphorus and potash content of the research field were found to be medium, high and medium respectively.

\section{Land preparation}

The land was ploughed and leveled once on $5^{\text {th }}$ March 2020. On March 9, 2020, FYM (500kg) was applied to the experimental plot, and the field was ploughed, fined, and pulverized. The recommended dose of NPK (75:50:50) was applied in the field according to the National ginger Research Program Kapurkot, Salyan. The whole field was divided into 20 plots each with a $3.6 \mathrm{~m}^{2}$ area. Each small plot was separated with rope on each side. Treated rhizomes were planted on $9^{\text {th }}$ March 2020.

\section{Pre-sowing rhizome treatment and planting}

Selected rhizomes of uniform sized were dipped in solution Carbendazim 50\% WP @ 1gm/litre + Mancozeb 75\% WP @ 2.5gm/ litre, Metalaxyl 8\% WP @ + Mancozeb 64\% WP @ 2gm/litre, Carbendazim 50\% WP @1gm/litre and Trichoderma viride 5gm/ litre for one hour and kept under shade for 5 hours and planted in respective field but in case of Trichoderma viride, soil application was also done at the sowing time. In control, seed dipped in the water for 60 minutes.

\section{Seed sowing}

Treated rhizomes were planted on $9^{\text {th }}$ March 2020. Rhizomes were planted at the $30 \mathrm{~cm}$ row to row and also $30 \mathrm{~cm}$ rhizome to rhizome. 40 pieces of rhizomes were planted in the individual plot. The local variety of ginger was taken as a test crop.

\section{Mulching}

After planting all the treated rhizomes in the respective plot, mulching was done on each experimental unit using the locally available mulching materials. The materials used for mulching was pine leaf.

\section{Weeding}

The periodic field visit was carried out for observing the growth of ginger. Weeding was done at a regular interval of 15 days after the second month of planting.

\section{Confirmation of disease and pathogen}

The diseased rhizome was washed, cut into small pieces and thereby sterilization process is carried out. The diseased rhizome was teased with the help of a sterilized teasing needle and observed under a compound microscope (Figure 3).

\section{Observation of the parameters}

Germination percentage: It is an estimate of the viability of a population of rhizomes. Germination count was done 95DAP and continued up to 110 DAP at 5 days intervals [33].

Germination Percentage $=\frac{\text { Rhizomes germinated }}{\text { Total rhizomes planted }} \times 100$

Pseudo-stem height $(\mathbf{c m})$ : The height of the Pseudo-stem was measured from the ground level to the uppermost leaf base from the ten randomly selected plants per plot and the average of the height of the sample pseudo-stem was calculated. It was measured after 95 DAPs till 123 DAPs at 7 days intervals.

Leaf number of clum: The leaf number of the clum was counted from ten randomly selected plants per plot and the average of the leaf number of samples clum was calculated. It was counted after ninetyfive days of planting 7 days till 123 DAPs.

Tiller number of clum: The tiller number of the clum was counted from ten randomly selected plants per plot and the average tiller number of samples clum was counted. It was counted after 120 days of planting till 140 DAPs at 10 days intervals and final data was taken in 170 DAPs.

Disease incidence and severity: Disease incidence in an experimental plot is simply the occurrence of the disease in the clum out of the total clum germinated in each experimental group. In an experimental plot, disease severity is simply the number of diseased pseudo-stems out of the total pseudo-stems germinated in each experiment.

To calculate the disease incidence total clum of each experimental unit was taken as the sample whereas the total pseudo-stems of each experimental plot were taken as the sample for calculation of severity of disease. Out of these, total infected clums were counted to calculate the disease incidence whereas the total numbers of pseudo-stems showing the symptoms of rhizome rot were counted. Rhizome rot incidence and severity was recorded for the first time at 120 days after planting and counted up to 140 after planting at the interval of 7 days also the final data was taken in 170 DAPs. The incidence and severity of the disease were calculated based on the following formula as reported in the research data book of NGRP, NARC $[33,34]$.

$$
\begin{aligned}
& \text { Disease Incidence }(\%)=\frac{\text { Total infeted clum }}{\text { Total clum per plot }} \times 100 \\
& \text { Disease severity }(\%)=\frac{\text { Total pseudostems infected }}{\text { Number of pseudostems (per plot) }} \times 100 \\
& \% \text { Disease control }=\frac{\text { Variation in Disease severity (Control-Treatment) }}{\text { Disease severity (Control) }} \times 100
\end{aligned}
$$

\section{Data entry Statistical analysis}

The data entry was done in MS-Excel and analysis was done using R-STAT software. Duncan test was carried out at a 5\% level of significance (Table 3 ).

\section{Result and Discussion}

A field experiment was conducted during the summer season of 2020 to identify suitable fungicides to control rhizome rot disease for optimum production at Bagchaur Municipality-3 in the Salyan 
Table 3: Data entry Statistical analysis.

Table 3: Data entry Statistical analysis.
\begin{tabular}{|c|r|r|r|}
\hline & Degree of freedom & Sum of Square & Mean square \\
\hline Replication & $(\mathrm{r}-1)=3$ & \\
\hline Treatment & $(\mathrm{t}-1)=4$ & \\
\hline Residuals & $(\mathrm{r}-1)(\mathrm{t}-1)=12$ & \\
\hline
\end{tabular}
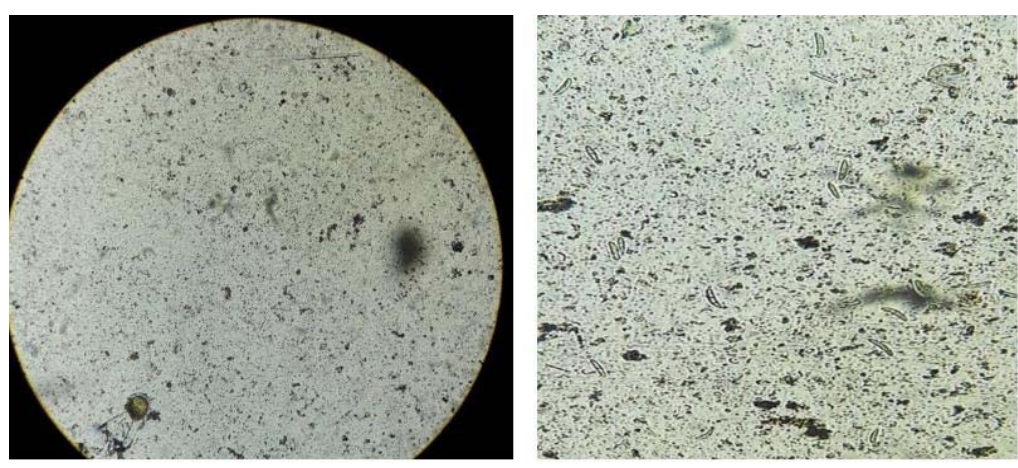

Figure 4: Pathogen observed under the microscope.

Table 4: Mean plant height of pseudo-stems at different days of planting under field condition in Bagchaur, Salyan, 2020.

\begin{tabular}{|c|c|c|c|c|c|}
\hline \multirow{2}{*}{ Treatment } & \multicolumn{5}{|c|}{ Plant height(cm) } \\
\hline & 95DAP & 102DAP & 109DAP & 116DAP & 123DAP \\
\hline Carbendazim 50\% WP @ 1gm/litre + Mancozeb 75\% WP @ 2.5gm/litre & 32.65 & 50.67 & 56.4 & 63.8 & 73.1 \\
\hline Metalaxyl 8\% WP+ Mancozeb 64\% WP @ 2gm/litre & 31.05 & 46.6 & 56.35 & 65.25 & 73.25 \\
\hline Carbendazim 50\% WP @1gm/litre & 33.43 & 50.85 & 60.37 & 68.8 & 77.37 \\
\hline Trichoderma viride @ 5gm/litre & 29.43 & 46.5 & 58.57 & 66.9 & 74.02 \\
\hline Control & 32.98 & 48.5 & 55.47 & 66.4 & 74.65 \\
\hline Grand mean & 31.9 & 48.65 & 57.43 & 66.23 & 74.48 \\
\hline SEm \pm & 2.05 & 1.77 & 2.08 & 2.65 & 2.14 \\
\hline CV (\%) & 12.9 & 7.31 & 7.27 & 7.99 & 5.74 \\
\hline Significance & ns & Ns & ns & ns & ns \\
\hline LSD (0.05) & - & - & - & - & - \\
\hline P-value & 0.64 & 0.3 & 0.48 & 0.74 & 0.63 \\
\hline
\end{tabular}

SEmะ: Standard Error of Mean; CV: Coefficient of Variation; LSD: Least Significant Difference; ns: Non-Significant; P-value: Probability value; DAP: Days After Planting.

district.

The pathogen of ginger rhizome rot was tested in the AFU lab by teasing method and observed in a microscope. Thus, from this lab test, it is confirmed that the disease observed in the field was dry rot Caused by Fusarium spp (Figure 4).

The growth parameters germination, plant height, number of leaves and number of tillers per plant and disease incidence, severity and disease control related observation were described below.

\section{Plant height}

Plant height $(\mathrm{cm})$ of ginger was recorded at 95, 102, 109, 116 and 123 DAP and the result is stated in Table 4. The height of pseudostems was found statistically similar in all treatments at 95, 102, 109, 116 and123 DAP. Plant height was recorded maximum $(33.43 \mathrm{~cm})$ in Carbendazim 50\% WP @ 1gm/litres at 95 DAP and minimum height of plant was recorded in $(29.43 \mathrm{~cm})$ Trichoderma viride @ 5gm/litre. Similarly maximum height of plant was recorded $50.85 \mathrm{~cm}, 60.37 \mathrm{~cm}$,
$68.80 \mathrm{~cm}$ and $77.37 \mathrm{~cm}$ in Carbendzazim 50\% WP @ 1gm/litre at 102, 109, 116 and 123 DAP respectively.

According to National ginger research program report (2012/13), height of pseudostems was found no significant differences among (0.1\%) Carbendazim 50\% WP + (0.25\%) Mancozeb 75\% WP, Trichoderma seed treatment and soil application, and, (0.2\%) Metalaxyl 8\% + Mancozeb 64\% WP. Similarly, pseudo-stems height was found no significant difference among Metalaxyl 8\% WP + Mancozeb 64\% WP, Mancozeb 75\% WP and Carbendazim 50\% WP Pre sowing rhizome treatment [28].

From above Table 4, the height of pseudo-stems was statistically similar in all treatments at 95, 102, 109, 116 and 123 DAP. Rhizome rot disease is more common during rainy seasons [8]. Fungicides used in the research were contacted (Mancozeb 75\% WP) and systemic (Carbendazim 50\% WP and Metalaxyl 8\% WP) but not growth regulator hormones. So, the height of pseudostems was found statistically similar in all treatments at 95, 102, 109, 116 and 123 DAP. 
Table 5: Mean plant leaf number at different days of planting under field condition in Bagchaur, Salyan 2020.

\begin{tabular}{|c|c|c|c|c|c|}
\hline \multirow{2}{*}{ Treatment } & \multicolumn{5}{|c|}{ Leaf number } \\
\hline & 95DAP & 102DAP & 109DAP & 116DAP & 123DAP \\
\hline Carbendazim 50\% WP @ 1gm/litre + Mancozeb 75\% WP @ 2.5gm/litre & 2.25 & 3.9 & 5.6 & 8.15 & 10.82 \\
\hline Metalaxyl 8\% WP+ Mancozeb 64\% WP @ 2gm/litre & 2.17 & 3.85 & 6.07 & 8.27 & 11.42 \\
\hline Carbendazim 50\% WP @1gm/litre & 1.77 & 3.45 & 5.42 & 7.92 & 11 \\
\hline Trichoderma viride @ 5gm/litre & 2.25 & 3.9 & 5.6 & 8.02 & 11.22 \\
\hline Control & 1.9 & 3.7 & 5.7 & 8.4 & 11.45 \\
\hline Grand mean & 2.05 & 3.75 & 5.68 & 8.15 & 11.18 \\
\hline SEm \pm & 0.15 & 0.22 & 0.31 & 0.35 & 0.44 \\
\hline CV (\%) & 14.99 & 11.8 & 11 & 8.66 & 7.84 \\
\hline Significance & ns & Ns & ns & ns & ns \\
\hline $\operatorname{LSD}(0.05)$ & - & - & - & - & - \\
\hline P-value & 0.17 & 0.57 & 0.67 & 0.87 & 0.81 \\
\hline
\end{tabular}

SEmะ: Standard Error of Mean; CV: Coefficient of Variation; LSD: Least Significant Difference; ns: Non-Significant; P-value: Probability value; DAP: Days Afte Planting.

Table 6: Mean plant germination percentage at the different days of planting under field condition in Bagchaur, Salyan 2020.

\begin{tabular}{|c|c|c|c|c|c|}
\hline \multirow{2}{*}{ Treatment } & \multicolumn{5}{|c|}{ Germination percentage (\%) } \\
\hline & 90DAP & 95DAP & 100DAP & 105DAP & 110DAP \\
\hline Carbendazim 50\% WP @ 1gm/litre + Mancozeb 75\% WP @ 2.5gm/litre & 50.11 & 69.37 & 88.12 & 95.62 & 96.87 \\
\hline Metalaxyl 8\% WP + Mancozeb 64\% WP @ 2gm/litre & 45.65 & 65 & 80.62 & 91.25 & 94.37 \\
\hline Carbendazim 50\% WP @1gm/litre & 41.87 & 68.12 & 88.12 & 91.25 & 94.37 \\
\hline Trichoderma viride @ 5gm/litre & 41.87 & 68.75 & 87.5 & 93.12 & 95 \\
\hline Control & 47.5 & 64.37 & 85.62 & 890.62 & 95.62 \\
\hline Grand mean & 45.25 & 67.12 & 86 & 92.37 & 95.25 \\
\hline SEm \pm & 6.77 & 6.6 & 4.75 & 4 & 2.68 \\
\hline CV (\%) & 29.95 & 19.68 & 11.05 & 8.66 & 5.62 \\
\hline Significance & ns & Ns & ns & ns & Ns \\
\hline $\operatorname{LSD}(0.05)$ & - & - & - & - & - \\
\hline
\end{tabular}

SEmะ: Standard Error of Mean; CV: Coefficient of Variation; LSD: Least Significant Difference; ns: Non-Significant; P-value: Probability value; DAP: Days After Planting.

\section{Number of leaves per plant}

The number of leaves per plant of ginger was recorded at 95, $102,109,116$, and 123 DAP and the results are presented in Table 5. Leaf number of clums was statistically similar in all treatments at 95, 102, 109, 116 and 123DAP. Rhizome rot mainly occurred during the season of July-August. Leaf number per plant is decreasing only when rhizome rot occurred in the field. So, the number of leaves per plant was statistically similar in all treatments.

At 120DAP, leaves/ plants were not found significantly different among (26.89) Carbendazim 50\% WP @ 1gm/litre, (27.03), Metalaxyl 8\% + Mancozeb 64\% @ 2gm/litre and (26.89) control [26] which is similar to above result.

\section{Rhizome germination}

The germination percentage of ginger was recorded at 90, 95, 100, 105 and 110 DAP and the result are presented in Table 6. The germination percentage was statistically similar in all treatments at 90, 95, 100, 105 and 110 DAP.
Rhizome rot disease is more common during rainy seasons [8]. Fungicides used in the research were contacted (Mancozeb 75\% WP) and systemic (Carbendazim 50\% WP and Metalaxyl 8\% WP) but not germination stimulating hormones. Disease-free rhizomes were planted in the research field. So that the germination percentage was statistically similar in all treatments at 90, 95, 100, 105 and 110 DAP.

\section{Number of tillers per clump}

At 120 DAP and 130 DAP, there was no significant difference among the fungicides in the case of tiller number. Rhizome rot disease occurs in the field during July, August and September. At 120 DAP, tiller number was found no significant difference among Carbendazim 50\% and Metalaxyl 8\% + Mancozeb 64\% [26], which is similar to the above result. At 140 DAP, tiller number was found the highest with Carbendazim 50\% WP @ 1gm/litre + Mancozeb 75\% @ $2.5 \mathrm{gm} /$ litre (1.30) which was statistically similar with the Metalaxyl 8\% WP + Mancozeb 64\% @ 2gm/litre (1.25) and Carbendazim 50\% WP @ 1gm/litre (1.17). Tiller number with the Carbendazim 50\% WP @ $1 \mathrm{gm} /$ litre was 1.17 which is statistically similar to with Trichoderma 
Table 7: Mean plant tiller number at different days of planting under field condition in Bagchaur, Salyan 2020.

\begin{tabular}{|c|c|c|c|c|}
\hline \multirow{2}{*}{ Treatment } & \multicolumn{4}{|c|}{ Tiller number } \\
\hline & 120DAP & 130DAP & 140DAP & 170DAP \\
\hline Carbendazim 50\% WP @ 1gm/litre + Mancozeb 75 \% WP @ 2.5gm/litre & 0.63 & 1 & $1.30^{\mathrm{a}}$ & $3.40^{\mathrm{a}}$ \\
\hline Metalaxyl 8\% WP+ Mancozeb 64\% WP @ 2gm/litre & 0.7 & 1.03 & $1.25^{\mathrm{ab}}$ & $3.23^{\mathrm{ab}}$ \\
\hline Carbendazim 50\% WP @1 gm/litre & 0.65 & 0.95 & $1.17^{\mathrm{ab}}$ & $3.17^{\mathrm{b}}$ \\
\hline Trichoderma viride @ 5gm/litre & 0.47 & 0.85 & $1.07^{\mathrm{bc}}$ & $3.05^{\mathrm{bc}}$ \\
\hline Control & 0.6 & 0.82 & $0.91^{c}$ & $2.95^{c}$ \\
\hline Grand mean & 0.61 & 0.93 & 1.15 & 3.16 \\
\hline SEm \pm & 0.09 & 0.08 & 0.06 & 0.05 \\
\hline CV (\%) & 31.37 & 19.25 & 11.14 & 3.59 \\
\hline Significance & ns & ns & $\mathrm{s}$ & $S$ \\
\hline $\operatorname{LSD}(0.05)$ & - & - & 0.19 & 0.17 \\
\hline P-value & 0.57 & 0.45 & $0.015^{*}$ & $0.001^{* *}$ \\
\hline
\end{tabular}

SEmะ: Standard Error of Mean; CV: Coefficient of Variation; LSD: Least Significant Difference; ns: Non-Significant; P-value: Probability value; DAP: Days After Planting; s: significant; *: significant; same letters in the superscript indicates the similar effect.

Table 8: Mean plant disease incidence at different days of planting under field condition in Bagchaur, Salyan, 2020.

\begin{tabular}{|c|c|c|c|c|}
\hline \multirow{2}{*}{ Treatment } & \multicolumn{4}{|c|}{ \% Disease incidence } \\
\hline & 120DAP & 130DAP & 140DAP & 170DAP \\
\hline Carbendazim 50\% WP @ 1gm/litre\& Mancozeb 75 \% WP @ 2.5gm/litre & $2.58^{\mathrm{c}}(1.75)$ & $2.58^{\mathrm{c}}(1.75)$ & $4.41^{\circ}(2.19)$ & $5.62^{\mathrm{d}}(2.53)$ \\
\hline Metalaxyl 8\% WP+ Mancozeb 64\% WP @ 2 gm/litre & $4.04^{\mathrm{bc}}(2.1)$ & $4.67^{\mathrm{bc}}(2.25)$ & $6.43^{\mathrm{bc}}(2.62)$ & $10^{\text {cd }}(3.06)$ \\
\hline Carbendazim 50\% WP @1gm/litre & $4.02^{\mathrm{bc}}(2.09)$ & $6.67^{\mathrm{b}}(2.66)$ & $7.02^{\mathrm{b}}(2.73)$ & $15.63^{\mathrm{bc}}(3.97)$ \\
\hline Trichoderma viride@ 5gm/litre & $5.25^{\mathrm{ab}}(2.36)$ & $6.58^{b}(2.59)$ & $8.75^{\mathrm{b}}(3.02)$ & $23.75^{\mathrm{ab}}(4.91)$ \\
\hline Control & $6.548^{\mathrm{a}}(2.65)$ & $9.85^{\mathrm{a}}(3.21)$ & $14.18^{\mathrm{a}}(3.829)$ & $34.37^{\mathrm{a}}(5.89)$ \\
\hline Grand mean & $4.48(2.19)$ & $6.07(2.49)$ & $8.1599(2.879)$ & $17.87(4.05)$ \\
\hline SEm \pm & 0.15 & 0.17 & 0.16 & 0.36 \\
\hline CV\% & 13.93 & 14.21 & 11.04 & 18.14 \\
\hline $\operatorname{LSD}(0.05)$ & 0.47 & 0.54 & 0.4897 & 1.13 \\
\hline P-value & $0.01574^{*}$ & $0.001^{* *}$ & $0.0014^{* * *}$ & $0.00016^{\star * *}$ \\
\hline
\end{tabular}

SEmะ: Standard Error of Mean; CV: Coefficient of Variation; LSD: Least Significant Difference; *: significant; **: highly significant; P-value: Probability value; DAP: Days After Planting; same letters in the superscript indicates the similar effect, Value in parenthesis indicate square root transformation sqrt( $\mathrm{x}+0.5)$.

viride@ 5gm/litre (1.07) (Table 7).

At 170DAP, the tiller number was the highest with the Carbendazim 50\% WP @ 1gm/litre + Mancozeb 75\% @ 2.5gm/ litre (3.40) which was statistically similar with the Metalaxyl $8 \%$ WP + Mancozeb 64\% @ 2gm/litre (3.23). Tiller number with the Carbendazim 50\% WP @1gm/litre was 3.17 which is statistically similar to with Trichoderma viride @ 5gm/litre (3.05). This result is under (20), according to them, Metalaxyl $4 \%$ WP + Mancozeb 64\% WP gives better results than Trichoderma viride in case of number of tillers. According to [35], Trichoderma spp. against soil-borne pathogens of fungus such as Pythium and Fusarium spp. is a very difficult task because of rapid germination of sporangia of Pythium spp. and immediate cause of secondary infection during rainy seasons lead to subsequent progress in an infection leading to further longterm rot of rhizome.

Fungicides used in the research were contact and systemic. Carbendazim is a systemic fungicide and Mancozeb is a contact fungicide. So, the combination of both helps to control the rhizome rot of ginger. The minimum tiller number (0.91) was found with control which may be rotting of some tiller and bud during germination.

\section{Disease incidence}

At 120 DAP, the highest disease incidence was observed with control (6.54) which was statistically similar with Trichoderma viride @ 5gm/litre (5.25) and the lowest disease incidence (2.58) was found with Carbendazim 50\% WP @ 1gm/litre + Mancozeb 75\% WP @ $2.5 \mathrm{gm} /$ litre (2.58) which was statistically similar with Metalaxyl $8 \%$ WP+ Mancozeb 64\% WP @ 2gm/litre (4.04) and Carbendazim 50\% WP@1gm/litre (4.02) (Table 8).

At 130 DAP, the highest disease incidence was observed with control (9.85) and the lowest disease incidence was found with Carbendazim 50\% WP @1gm/litre + Mancozeb 75\% WP @ 2.5gm/ litre (2.58) which was statistically similar with Metalaxyl 8\% WP + Mancozeb 64\% WP @ 2gm/litre (4.67). The incidence of disease with the Carbendazim 50\% WP @ 1gm/litre was 6.67 which is statistically similar to Trichoderma viride @ 5gm/litre (6.58).

At 140 DAP, the highest incidence of disease was found with control plot (14.18) and the lowest disease incidence was found 
Table 9: Mean plant disease severity at different days of planting under field condition in Bagchaur, Salyan, 2020.

\begin{tabular}{|c|c|c|c|c|}
\hline \multirow{2}{*}{ Treatment } & \multicolumn{4}{|c|}{$\%$ Disease severity } \\
\hline & 120DAP & 130DAP & 140DAP & 170DAP \\
\hline Carbendazim 50\% WP@1gm/litre+ Mancozeb 75\% WP @2.5gm/litre & $2.46^{\mathrm{c}}(1.72)$ & $2.45^{\mathrm{d}}(1.7)$ & $2.52^{\mathrm{d}}(1.72)$ & $4.32^{\mathrm{d}}(2.18)$ \\
\hline Metalaxyl 8\% WP+ Mancozeb 64\% WP @2gm/litre & $2.53^{c}(1.72)$ & $2.88^{\mathrm{cd}}(1.81)$ & $5.05^{\mathrm{c}}(2.35)$ & $7.99^{\mathrm{c}}(2.9)$ \\
\hline Carbendazim 50\% WP @1gm/litre & $3.89^{\mathrm{bc}}(2.09)$ & $4.04^{\mathrm{c}}(2.12)$ & $5.46^{\mathrm{bc}}(2.43)$ & $10.60^{\mathrm{bc}}(3.33)$ \\
\hline Trichoderma viride @5gm/litre & $5.21^{\mathrm{ab}}(2.36)$ & $6.18^{\mathrm{b}}(2.57)$ & $7.48^{\mathrm{b}}(2.82)$ & $13.77^{\mathrm{b}}(3.77)$ \\
\hline Control & $6.23^{\mathrm{a}}(2.58)$ & $9.67^{\mathrm{a}}(3.18)$ & $12.92^{\mathrm{a}}(3.66)$ & $30.03^{a}(5.5)$ \\
\hline Grand mean & $4.06(2.09)$ & $5.04(2.28)$ & $6.68(2.59)$ & $13.34(3.54)$ \\
\hline SEm \pm & 0.13 & 0.13 & 0.13 & 0.17 \\
\hline CV\% & 12.72 & 11.29 & 9.84 & 9.62 \\
\hline $\operatorname{LSD}(0.05)$ & 0.41 & 0.39 & 0.39 & 0.52 \\
\hline
\end{tabular}

SEmะ: Standard Error of Mean; CV: Coefficient of Variation; LSD: Least Significant Difference; *: significant; **: highly significant; P-value: Probability value; DAP: Days After Planting; same letters in the superscript indicates the similar effect, Value in parenthesis indicate square root transformation sqrt( $\mathrm{x}+0.5)$.

with Carbendazim 50\% WP @1gm/litre + Mancozeb 75\% WP @ $2.5 \mathrm{gm} /$ litre (4.41) was statistically similar with Metalaxyl $8 \%$ WP + Mancozeb 64\% WP @ 2gm/litre (6.43). The incidence of disease with the Carbendazim 50\% WP @ 1gm/litre was 7.02 which was statistically similar to Trichoderma viride@ $5 \mathrm{gm} /$ litre (8.75).

At 170 DAP, the highest disease incidence was observed with control (34.37) which was statistically similar with Trichoderma viride @ 5gm/litre (23.75) and followed by Carbendazim 50\% WP (15.63). The lowest disease incidence was observed with Carbendazim 50\% WP @ 1gm/litre + Mancozeb 75 \% WP @ 2.5gm/litre (5.62) which was statistically similar with Metalaxyl 8\% WP+ Mancozeb 64\% WP @ 2gm/litre [10].

Overall disease incidence was found to be the lowest with the Carbendazim 50\% WP @ 1gm/litre + Mancozeb 75\% WP @ 2.5gm/ litre treatment during the entire period of the experiment, where the highest disease incidence was observed with the control treatment. Thus, the combined use of systemic (Carbendazim 50\% WP @ 1gm/ litre) and contact (Mancozeb 75\% WP @ 2.5 gm/litre) fungicides were most effective against rhizome rot to minimize the disease incidence. The result of disease incidence is more or less similar with [29], according to them, seed treatment with Carbendazim 50\% WP + Chloropyriphos 20EC\% + (Carbendazim 12\% WP + Mancozeb $75 \% \mathrm{WP}$ ) is best compared to Metalaxyl 4\% WP + Mancozeb 64\% WP, Carbendazim 50\% WP and Trichoderma viride. According to the annual report (2012/13) of the National ginger research Program, Kapurkot, Salyan, rhizome rot incidence was the lowest with the Carbendazim 50\% WP @1gm/litre + Mancozeb 75\% WP @ 2.5gm/ litre treatment as compared to Trichoderma viride @ $5 \mathrm{gm} /$ litre treated rhizome which is similar to above result. Trichoderma viride seed treatment with soil application is safer management practice but disease incidence was found moderate. This finding was similar to reported by [36].

\section{Disease severity}

At 120 DAP, the highest disease severity was observed with control (6.24) which was statistically similar with Trichoderma viride @ 5gm/litre (5.21) and the lowest disease severity was observed with Carbendazim 50\% WP @ 1gm/litre + Mancozeb 75\% WP @ 2.5gm/ litre (2.46) which was statistically similar with Metalaxyl $8 \%$ WP+
Mancozeb 64\% WP @ 2gm/litre (2.53) and Carbendazim 50\% WP @ 1gm/litre (3.89) (Table 9).

At 130 DAP, highest disease severity was observed with control (9.67) and lowest disease severity was observed with Carbendazim 50\%WP@1gm/litre + Mancozeb 75\% WP @ 2.5gm/litre (2.45) which was statistically similar with Metalaxyl 8\% WP + Mancozeb 64\% WP@ 2gm/litre (2.88) and followed by Carbendazim 50\% WP @ $1 \mathrm{gm} / \mathrm{litre}$ (4.04) and Trichoderma viride @ 5gm/litre (6.18).

At 140 DAP, highest disease severity (12.918) was found with control (12.91) and the lowest disease severity (2.52) was observed with Carbendazim 50\% WP @ 1gm/litre + Mancozeb 75\% WP @ $2.5 \mathrm{gm} /$ litre (2.52) and followed by Metalaxyl 8\% WP + Mancozeb 64\%WP@2gm/litre (5.05) which was statistically similar with Carbendazim 50\% WP @ 1gm/litre (5.46). Disease incidence in Carbendazim 50\% WP @ 1gm/litre (5.46) was statistically similar with Trichoderma viride @ 5gm/litre (7.48).

At 170DAP, highest disease severity was observed with control (30.03) treatment and the lowest disease severity was observed with Carbendazim 50\% WP @ 1gm/litre + Mancozeb 75\% WP @ 2.5gm/ litre (4.32) and followed by Metalaxyl 8\% WP + Mancozeb 64\% WP @ $2 \mathrm{gm} /$ litre (7.99) which was statistically similar with Carbendazim $50 \%$ WP @ 1gm/litre (10.60). Disease incidence with Carbendazim 50\% WP @ 1gm/litre (10.60) was statistically similar with Trichoderma viride@ 5gm/litre (13.77).

Disease severity was found lowest with Carbendazim 50\% WP @ 1gm/litre + Mancozeb 75\% WP @ 2.5gm/litre treatment during the entire period of experiment. This shows that the combined use of systemic (Carbendazim 50\% WP @ 1gm/litre) and contact (Mancozeb 75\% WP @ $2.5 \mathrm{gm} /$ litre) fungicides are most effective against rhizome rot to minimize the disease severity. Carbendazim 50\% WP @ 1gm/ litre + Mancozeb 75\% WP @ 2.5gm/litre was the best with less disease severity [27], which was the similar with the result of this study.

At 170 DAP, the disease severity was found less (7.99) with Metalaxyl 8\%WP+ Mancozeb 64\% WP 2gm/litre treatment in comparison with the (10.60) Carbendazim 50\% WP 1gm/litre treatment because Metalaxyl is systemic and Mancozeb is contact fungicides but Carbendazim is the systemic fungicide. So, disease 
Table 10: Effects of different fungicides in the percentage disease control over control at 170 days planting in Bagchaur, Salyan, 2020.

\begin{tabular}{|c|c|}
\hline Treatment & \\
\hline Carbendazim 50\% WP @1gm/litre + Mancozeb 75\% WP @2.5gm/ litre & Disease control (170 DAP) \\
\hline Metalaxyl 8\% WP + Mancozeb 64\% WP @2gm/litre & $85.61 \%$ \\
\hline Carbendazim 50\% WP @1 $1 \mathrm{gm} /$ litre & $73.39 \%$ \\
\hline Trichoderma viride @ $5 \mathrm{gm} /$ litre & $64.70 \%$ \\
\hline
\end{tabular}

\section{DAP: Days After Planting.}

severity was found more with Carbendazim 50\% WP treatment. At 240DAP, disease severity was found less with Metalaxyl 8\%WP+ Mancozeb 64\% WP treatment in comparison with the Carbendazim $50 \%$ WP treatment (37), which was the accordance with the result of this study.

\section{Disease control}

The highest percentage of disease control was found with Carbendazim 50\% WP @ 1gm/litre + Mancozeb 75\% WP @ 2.5gm/ litre (85.61\%) and followed by Metalaxyl 8\% + Mancozeb 64\% @ 2gm/litre (73.39\%) and Carbendazim 50\% WP @ 1gm/litre (64.70\%). The lowest percentage of disease control $(54.14 \%)$ was found in Trichoderma viride@ 5gm/litre (Table 10).

\section{Conclusion}

Ginger is the most important spice crop grown in the mid-hills of Nepal as a High-Value Crop (HVCS). Ginger has a medicinal value which is used as antimicrobial, antioxidant and anti-inflammatory agents. Ginger is affected by many fungal, bacterial, viral and Mycoplasma origins. Among them, rhizome rot is considered one of the most prevalent and challenging diseases of ginger causing a significant yield loss and damage. An experiment was conducted regarding the effectiveness of different fungicides against rhizome rot disease under farmer's field conditions at Bagchaur-3, Salyan during the summer season of 2020. The field experiment was conducted under Randomized Complete Block Design (RCBD) with four replication and five treatments Carbendazim 50\% WP @1gm/litre + Mancozeb 75\%WP @ 2.5gm/litre, Metalaxyl 8\% WP + Mancozeb 64\% WP @ 2gm/litre, Carbendazim 50\%WP @ 1gm/litre,Trichoderma viride@ $5 \mathrm{gm} /$ litre and control in the experimental area of $130 \mathrm{~m}^{2}$. The tiller number was calculated and considerable differences were observed ranging from the lowest tiller number with control treatment and highest with Carbendazim 50\% WP @ 1gm/litre + Mancozeb 75\% WP @ 2.5gm/litre treatment at 130 and 170 days after sowing but tiller number did not vary significantly at 120 and 130 days after planting. Disease incidence was found lowest with the Carbendazim 50\% WP @ 1gm/litre + Mancozeb 75\% WP @ 2.5gm/litre treatment during the entire research period where the highest disease incidence was observed with the control treatment in 120,130, 140 and 170 days after planting. Disease severity was also found lowest with Carbendazim 50\% WP @ 1gm/litre + Mancozeb 75\% WP @ 2.5gm/litre treatment during the entire research period whereas the highest disease severity was observed with the control treatment at 120,130, 140 and 170 days after planting. The highest percentage of disease control was found with the Carbendazim 50\% WP @ 1gm/litre + Mancozeb 75\% WP @ 2.5gm/litre (85.61\%) treatment followed by Metalaxyl 8\%WP + Mancozeb 64\% WP @ 2gm/litre (73.39\%) and Carbendazim 50\% WP @ 1gm/litre (64.70) whereas lowest percentage of disease control was observed with the Trichoderma viride@ $9 \mathrm{gm} /$ litre treatment
(54.14). Thus, it is concluded that Carbendazim 50\% WP $1 \mathrm{gm} / \mathrm{litre}$ + Mancozeb 75\% WP @ 2.5gm/litre was effective fungicides among other fungicides against rhizome rot disease of ginger in Bagchaur-3, Salyan. Hence, to minimize the burning problem of rhizome rot in ginger farming in Bagchaur, Salyan, the farmers are suggested to use both Carbendazim 50\% WP @ 1gm/litre + Mancozeb 75\% WP @ $2.5 \mathrm{gm} /$ litre water for pre-sowing rhizome treatment.

\section{References}

1. MOAC. A Report on Value chain analysis of Ginger subsector in Nepal Prepared by ANSAB (Asia Network for Sustainable Agriculture and Bioresources. 2010.

2. KC G. Ginger cultivation technology. Leaflets in nepali language. Nepa Agriculture Research Council, Ginger Research Program, Kapurkot, Salyan 2010. 2010.

3. Khanal K. Factors Affecting and Marketing Chain of Ginger in Salyan District, Nepal. Int J Appl Sci Biotechnol. 2018; 6: 127-131.

4. MOALD. Ministry of Agriculture and Livestock Development. 2021.

5. Irfan S, Modassar Ali Nawaz Ranjha M, Mahmood S, Mueen-ud-Din G, Rehman S, Saeed W, et al. A Critical Review on Pharmaceutical and Medicinal Importance of Ginger. Acta Sci Nutr Heal. 2019; 3: 78-82.

6. Mao Q-Q, Xu X-Y, Cao S-Y, Gan R-Y, Corke H, Beta T, et al. Bioactive Compounds and Bioactivities of Ginger (Zingiber officinale Roscoe). Foods. 2019; 8.

7. Gupta M, Jebasingh T. Diseases of Ginger. Ginger: The Genus Zingiber. 2019; 305-340.

8. Sharma B, Shrestha S, Giri Y. "Present status of diseases and insect pests of ginger in Nepal". In: Proceedings of the second national horticulture research workshop on 13-15 May 1998, Khumaltar, Lalitpur, Nepal. Nepal Agriculture Research Council (NARC). 1998: 173-178.

9. Gautam J, Acharya B. Survey and monitoring of insect pest and disease of ginger in Nepal. Nepal J Agric Sci. 2014; 12: 118-123.

10. Rai S. Management of Ginger (Zingiber officinale Rosc.) Rhizome Rot in Darjeeling and Sikkim Himalayan Region. 2006.

11. Dake GN, Edison S. Association of pathogens with rhizome rot of ginger in Kerala. Indian Phytopathol. 1989; 42: 116-119.

12. Stirling GR, Turaganivalu U, Stirling AM, Lomavatu MF, Smith MK. Rhizome rot of ginger (Zingiber officinale) caused by Pythium myriotylum in Fiji and Australia. Australas Plant Pathol. 2009; 38: 453-460.

13. Kulkarni S. Etiology, epidemiology and integrated management of rhizome rot of ginger in Karnataka-Srikant Kulkarni. Indian Phytopathol. 2011.

14. NGRP. Annual Report-National Ginger Research Programme. 2012.

15. Jayasekhar M, Joshua JP, Pillai OAA. Management of rhizome rot of ginger caused by Pythium aphanidermatum. Madras Agric J. 2000; 87: 170-171.

16. Singh AK. Management of rhizome rot caused by Pythium, Fusarium and Ralstonia spp. in ginger (Ginger officinale) under natural field conditions. Indian J Agric Sci. 2011; 81: 268-270.

17. Gautam J, Mainali RP. Management of Ginger Rhizome Fly (Calobata $s p$.) and Associated Rhizome Rot (Pythium sp.). World J Agric Res. 2016; 4: 128131. 
18. Khatso K, Tiameren Ao N. Biocontrol of rhizome rot disease of ginger (Zingiber officinale Rosc.). Int J Bio-resource Stress Manag. 2013; 4: 317-321.

19. Sharmah D, Bordaloi R, Tripathi AK. Management of ginger soft rot (Pythium aphanidermatum) in organic cultivation of ginger in Tripura, India. Biopestic Int. 2016; 12: 77-81.

20. Ayub A, Sultana N, Faruk MI, Rahman MM, Mamun ANM. Control of Rhizome Rot Disease of Ginger (Zingiber officinale Rose) by Chemicals, Soil Amendments and Soil Antagonis. Agric. 2009; 57-61.

21. NGRP. Annual Report- Ginger Research Programme. Salyan, Nepal. 2011.

22. Kandiannan K, Sivaraman K, Thankamani CK, Peter KV. Agronomy of ginger (Zingiber officinale Rosc.). J spices Aromat Crop. 1996; 5: 1-27.

23. Usaid. Value Chain/Market Analysis of the Ginger Sub-Sector in Nepal. 2011

24. Poudyal BK. Jeevatu: one of the best bio-agents for the control of soft rot of ginger. In: Proceedings $2^{\text {nd }}$ international conference on environment science and biotechnology, IPCBEE. 2012: 66-70.

25. MOALD. Statistical Information in Nepalese Agriculture. Ministry of Agriculture and Livestock Development. 2020; 290.

26. Hosain MK, Hossain SMM, Abedin Z, Islam MM, Rahman MA, Rahman MS, et al. Control of rhizome rot disease of ginger through application of fungicides. Asian Res J Agric. 2018; 1-9.

27. Acharya B, Regmi H. Evaluation and selection of appropriate management package of ginger rhizome rot disease in field condition. IOSR J Agric Ve Sci. 2015; 8: 0-4

28. Chowdhury EK, Hasan MM, Mustarin K, Hasan MS, Fancy R. Efficacy of different fungicides in controlling rhizome rot of ginger. J Agrofor Env. 2009; 3: $179-181$.
29. Jain DK, Swami H, Gangwar RK. Management of fungi, Pythium aphanidermatum causing rhizome rot disease of ginger (Zingiber officinale Rose) in Southern Rajasthan, India. Int J Curr Microbiol Appl Sci. 2020; 9: 903-911.

30. Wikipedia. Salyan Khalanga - Wikipedia. 2021

31. LGCDP. GIS District Map | Local Governance and Community Development Programme (LGCDP) - II.

32. Saupe DSG. Plant Physiology. College of St. Benedict/St. John's University Biology Department. 2009.

33. Degu T, Yaregal W, Gudisa T. Status of Common Bean (Phaseolus vulgaris L.) Diseases in Metekel Zone, North West Ethiopia. J Plant Pathol Microbiol. 2020; 11: 1-8.

34. Waghe KP, Wagh SS, Kuldhar DP, Pawar D V. Evaluation of different fungicides, bioagents and botanicals against Alternaria blight caused by Alternaria helianthi (Hansf) of sunflower. African J Agric Res. 2015; 10: 351 358.

35. Dohroo NP, Kansal S, Ahluwalia N. Studies on eco-farmer-friendly practices for management of soft rot of ginger (Zingiber officinale). Indian Phytopathol. 2015; 68: 93-96.

36. Dohroo NP, Sharma SL. Evaluation of fungicides for the control of rhizome rot of ginger in storage. Indian Phytopathol. 1983.

37. Hasnat M, Bose R, Hossain M, Anam M, Kabir H. Effect of chemicals, bioagent plants extract and soil amendments in controlling rhizome rot of ginger. 2014. 